\title{
Advanced in situ geochronological and trace element microanalysis by laser ablation techniques
}

\author{
Dirk Frei, Julie A. Hollis, Axel Gerdes, Dan Harlov, Christine Karlsson, Paulina Vasquez, \\ Gerhard Franz, Leif Johansson and Christian Knudsen
}

Laser ablation inductively coupled plasma mass spectrometry (LA-ICP-MS) was developed in 1985 and the first commercial laser ablation systems were introduced in the mid 1990s. Since then, LA-ICP-MS has become an important analytical tool in the earth sciences. Initially, the main interest for geologists was in its ability to quantitatively determine the contents of a wide range of elements in many minerals at very low concentrations (a few ppm and below) with relatively high spatial resolution (spot diameters of typically $30-100 \mu \mathrm{m}$ ). The potential of LA-ICP-MS for rapid in situ U-Th-Pb geochronology was already realised in the early to mid 1990s. However, the full potential of LA-ICP-MS as the low-cost alternative to ion-microprobe techniques for highly precise and accurate in situ $\mathrm{U}-\mathrm{Th}-\mathrm{Pb}$ age dating was not realised until the relatively recent advances in laser technologies and the introduction of magnetic sectorfield ICP-MS (SF-ICPMS) instruments. In March 2005, the Geological Survey of Denmark and Greenland (GEUS) commissioned a new laser ablation magnetic sectorfield inductively coupled plasma mass spectrometry (LA-SF-ICP-MS) facility employing a ThermoFinnigan Element2 high resolution magnetic sectorfield ICP-MS and a Merchantek New Wave 213 nm UV laser ablation system. The new GEUS LA-SF-ICP-MS facility is widely used on Survey research projects in Denmark and Greenland, as well as in collaborative research and contract projects conducted with partners from academia and industry worldwide. Here, we present examples from some of the these ongoing studies that highlight the application of the new facility for advanced geochronological and trace element in situ microanalysis of geomaterials. The application of LASF-ICP-MS based in situ zircon geochronology to regional studies addressing the Archaean geology of southern West Greenland is presented by Hollis et al. (2006, this volume).

\section{Zircon U-Pb geochronology using LA-SF-ICP-MS}

In situ $\mathrm{U}-\mathrm{Th}-\mathrm{Pb}$ geochronology was developed in the mid80 s with the introduction of ion-microprobe techniques, most commonly referred to as secondary ion mass spectrometry (SIMS) and sensitive high resolution ion microprobe (SHRIMP). The advantage of in situ U-Th-Pb geochronol- ogy over conventional chemical dating by isotope dilution thermal ionisation mass spectrometry (ID-TIMS) is the capability to analyse different domains in heterogeneous single zircons with high spatial resolution (spot diameters of typically $10-30 \mu \mathrm{m}$ ). This allows resolution of igneous and metamorphic events separated by intervals of only a few tens of million years from polychronic zircons. The disadvantages of ion-microprobe techniques are the very high purchasing and operating costs for the instrument. The rapid improvements in laser based U-Th-Pb geochronology makes it now possible to obtain in situ U-Th-Pb geochronological data with comparable spatial resolution as well as analytical precision and accuracy at only a fraction of the costs of ion-microprobe techniques (e.g. Jackson et al. 2004; Janoušek et al. 2006).

\section{Dating of magmatic and metamorphic events}

The capabilities of LA-SF-ICP-MS for the precise and accurate $\mathrm{U}-\mathrm{Pb}$ age dating of relatively young igneous zircons are demonstrated by the analysis of a population of 40 zircons extracted from a gabbro from the Coastal Cordillera at Tregualemu, central Southern Chile. The gabbro is believed to have been formed by regional extension during the late Triassic to early Jurassic (Charrier 1979). Three zircons proved to be too small for analysis $(<30 \mu \mathrm{m})$. The results for the remaining 37 zircons (Fig. 1) define a highly precise igneous concordia age of $203 \pm 2 \mathrm{Ma}(2 \sigma ; \mathrm{MSWD}=1.7)$ and indicate a Late Triassic (Rhaetian) intrusion age of the gabbro. An even

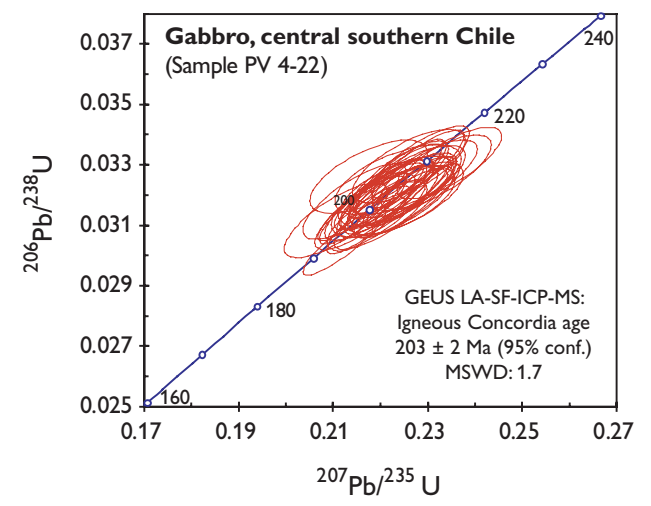

Fig. 1. Concordia diagram for igneous zircons from a gabbro from the Coastal Cordillera in central Southern Chile. 
younger igneous age of $158 \pm 2$ Ma was recently obtained for a zircon xeno- or phenocryst derived from a newly discovered carbonatite in southern West Greenland (Steenfelt et al. 2006, this volume).

The high sensitivity of the Element2 SF-ICP-MS allows $\mathrm{U}-\mathrm{Pb}$ zircon age dating with a laser spotsize of $30 \mu \mathrm{m}$ or less, depending on the $\mathrm{Pb}$ content of the zircons. This makes it feasible to analyse different age domains in polychronic zircons, e.g. igneous cores and metamorphic rims. For example, zircons from an orthogneiss from the Nuuk region, southern West Greenland, display characteristic textures in back-scattered electron (BSE) and cathodoluminescence (CL) pictures that are interpreted as igneous cores surrounded by rims grown during a metamorphic event (see inset in Fig. 2). The U-Pb age data of the cores suggest an emplacement of the igneous protolith at c. $3660 \mathrm{Ma}$, while the rim data indicate metamorphism close to $2700 \mathrm{Ma}$ (Fig. 2).

\section{Dating of detrital zircons}

Analyses of the crystallisation ages of detrital zircons in clastic sediments are a powerful tool in sedimentary provenance analysis. Accurate and precise U-Pb ages of $>100$ detrital zircon grains in a sample are needed to detect all major sedimentary source components with statistical confidence (cf. Vermeesch 2004; and references therein). The relatively high costs and the limited capacities of ion microprobe techniques (c. 75 zircon age analyses per day) impose restrictions on the number of samples that can be studied. Because LA-SF-ICPMS provides very high capacities (in excess of 300 zircon age analyses per day) without compromising accuracy and preci-

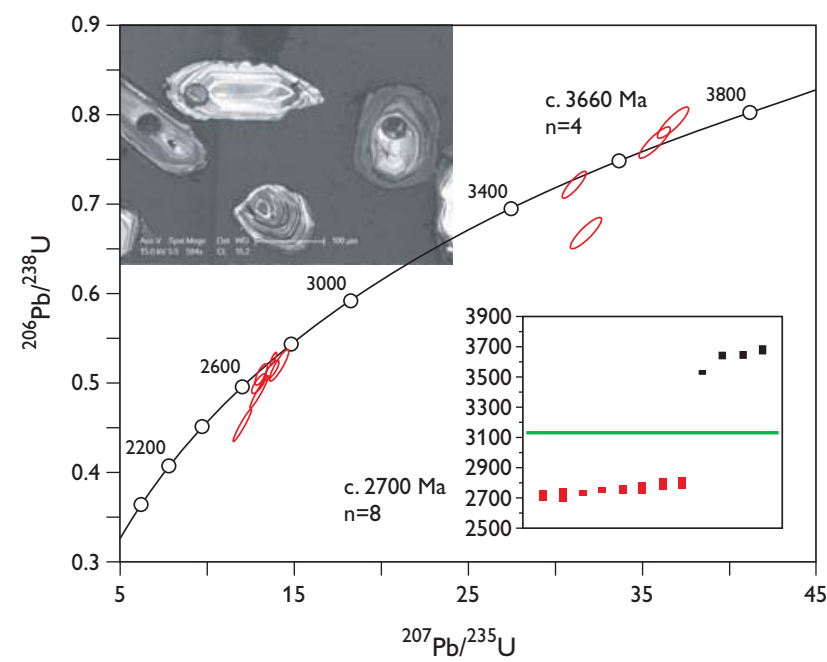

Fig. 2. Concordia diagram and inset of ${ }^{207} \mathrm{~Pb} /{ }^{206} \mathrm{~Pb}$ age plot for polychronic zircons from an orthogneiss in the Nuuk region, southern West Greenland. Inset CL image shows laser ablation pits (pit diameter $=30$ $\mu \mathrm{m})$ in igneous cores and metamorphic rims of polychronic zircons. Note the shallow depth (usually $<20 \mu \mathrm{m}$ ) of the laser ablation pits. sion, it constitutes the economic method of choice for provenance studies based on detrital zircon $\mathrm{U}-\mathrm{Pb}$ ages.

An example for detrital zircon age data obtained by LASF-ICP-MS is shown in Fig. 3, where the ${ }^{207} \mathrm{~Pb}-{ }^{206} \mathrm{~Pb}$ age distribution for a population of 100 zircon grains separated from a Cambrian sandstone from Torekov, southern Sweden, are shown in a combined histogram and probability density distribution (PPD) diagram. The concordance filtered zircons (dark shaded area; $90-110 \%$ concordance, defined as $100^{*}$ $\left[{ }^{206} \mathrm{~Pb}-{ }^{238} \mathrm{U}\right.$ age $/{ }^{207} \mathrm{~Pb}-{ }^{206} \mathrm{~Pb}$ age $\left.]\right)$ show a polymodal age distribution with a minor peak at $\sim 1000 \mathrm{Ma}$ and two major peaks at $c .1150 \mathrm{Ma}$ and $1650 \mathrm{Ma}$. The presence of two older sedimentary sources (c. $2150 \mathrm{Ma}$ and c. $3050 \mathrm{Ma}$ ) is indicated by discordant grains (lighter shaded grey areas) that most likely suffered lead loss during their petrogenetic evolution.

\section{Figures of merit}

The short and long term precision and accuracy of LA-SFICP-MS for U-Pb zircon age dating has been assessed using two zircon reference materials, Plesovice (with an ID-TIMS age of $338 \pm 1 \mathrm{Ma}$; Aftalion et al. 1989; provided by Jan Kosler, University of Bergen) and 91500 (ID-TIMS age = $1065 \pm 0.4 \mathrm{Ma}$; Wiedenbeck et al. 1995). The PL zircon is routinely analysed as unknown for quality control purposes in every analytical session in the GEUS laboratory. The results for 16 analyses of the zircon from a typical single analytical session are shown in Fig. 4A. They define a concordia age that is in excellent agreement with the ID-TIMS age

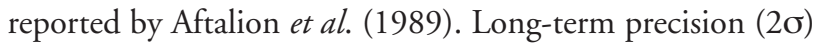
based on 109 analyses of the Plesovice zircon by two different operators was $2 \%, 2.3 \%$ and $1.1 \%$ for the ${ }^{206} \mathrm{~Pb} /{ }^{238} \mathrm{U}$, ${ }^{207} \mathrm{~Pb} /{ }^{235} \mathrm{U}$ and ${ }^{207} \mathrm{~Pb} /{ }^{206} \mathrm{~Pb}$ ratios, respectively. The widely used 91500 zircon has so far only been analysed during one analytical session. The results for all seven analyses carried out

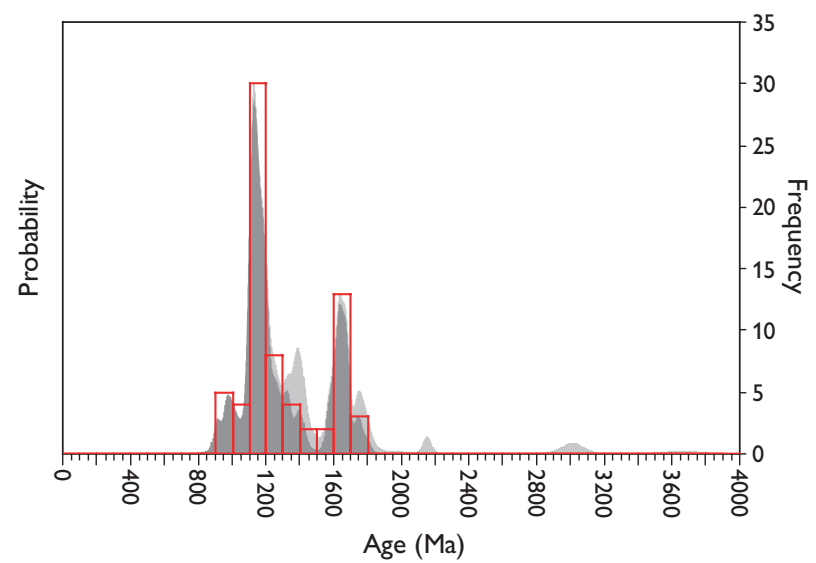

Fig. 3. Combined display of histogram and probability density distribution (PPD) diagram for zircons from a Cambrian sandstone from Torekov, south-western Sweden. See text for explanations. 
Fig. 4. Concordia diagrams for 16 analysis of the Plesovice zircon reference material obtained during a single analytical session (A); and 7 analysis of the 91500 zircon reference material obtained during a single analytical session (B).
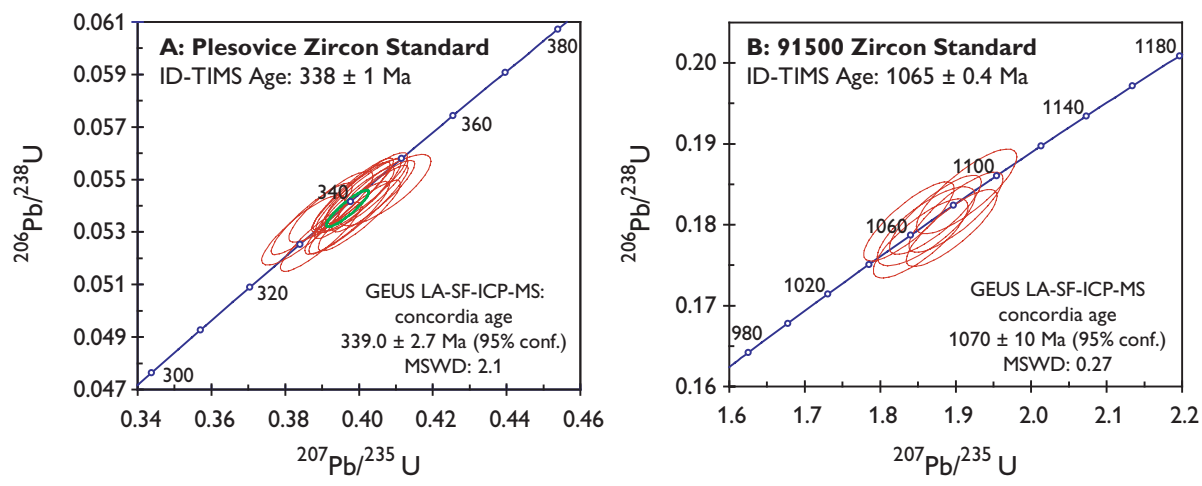

during this session (Fig. 4B) define a concordia age which is in excellent agreement with the ID-TIMS age reported by Wiedenbeck et al. (1995).

\section{Trace element analysis using LA-SF-ICP-MS}

Due mainly to the introduction of LA-ICP-MS techniques, the trace element signatures of individual minerals (e.g. garnet, clinopyroxene, epidote, rutile, calcite) are now frequently being used to deduce the petrogenetic evolution of magmatic rocks, unravel water-rock interactions, identify geotectonic settings and sediment sources, track down the pathways of potentially health-damaging pollutants, and to unravel the change of seasurface and atmospheric temperatures. Furthermore, LA-ICP-MS is an important tool for the characterisation of synthetically produced geomaterials.

\section{Water-rock interaction}

Fluid-mediated mass transfer during metamorphism and metasomatism is a hotly debated issue. Mobility of geochemically important trace elements during fluid flow has farreaching implications for e.g. ore-forming processes and mass transfer during subduction. Detailed investigation of the mechanisms of element mobility during fluid-rock interaction on a grain-scale are pivotal for an understanding of the processes that lead to the characteristic element enrichments and depletions observed in nature.

In the Söndrum stone quarry in Sweden, a localised dehydration zone of 2.5 to $3 \mathrm{~m}$ width occurs in garnet-bearing granitic gneiss around an approximately $1 \mathrm{~m}$ wide pegmatoid dyke. Whole-rock chemistry suggests that the solid-state dehydration of the granitic gneiss to charnokite via low $\mathrm{H}_{2} \mathrm{O}$ activity fluids consisting principally of $\mathrm{CO}_{2}$ and a minor brine component was predominantly isochemical (Harlov et al. 2006). Exceptions include $Y$ and the heavy rare earth elements (HREE), which are markedly depleted throughout the dehydration zone. In order to assess the mechanism of $Y$ and
HREE depletion, the trace element geochemistry of garnet was studied in a traverse across the dehydration zone. Garnets from the pristine, unaltered granitic gneiss are characterised by a strong negative Eu-anomaly and the steep, HREE enriched pattern typical for garnet (sample SD45-600 in Fig. 5). In contrast, garnets from within the dehydration zone show a less pronounced Eu-anomaly and are characterised by dramatic Y and HREE depletions, leading to almost flat REE pattern (sample SD9-120 in Fig. 5). This observation provides direct evidence for massive release of $Y$ and HREE from garnets, the principal hosts of these elements in the granitic gneiss, via solid-state fluid-rock interaction which was also accompanied by dehydration of hornblende and biotite to ortho- and clinopyroxene.

\section{Analysis of synthetic geomaterials}

Another application of LA-ICP-MS is the trace element analysis of synthetic geomaterials, e.g. products of experiments carried out for petrogenetical purposes. Since the experimentally produced mineral phases are usually very small, in situ microanalysis with high spatial resolution is needed. This was traditionally achieved by SIMS techniques. Because LAICP-MS analyses are much cheaper and facilities are much

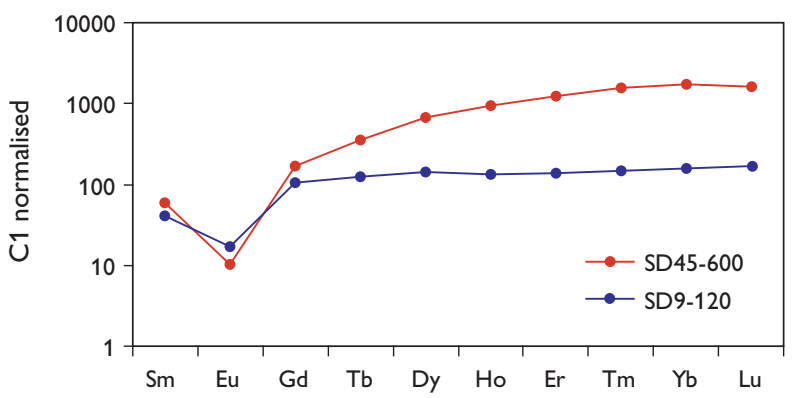

Fig. 5. Average chondrite-normalised REE-pattern of garnets from the unaffected granitic gneiss (SD45-600) and the dehydration zone (SD9120). Note the depletion in HREE of garnets from the dehydration zone. 


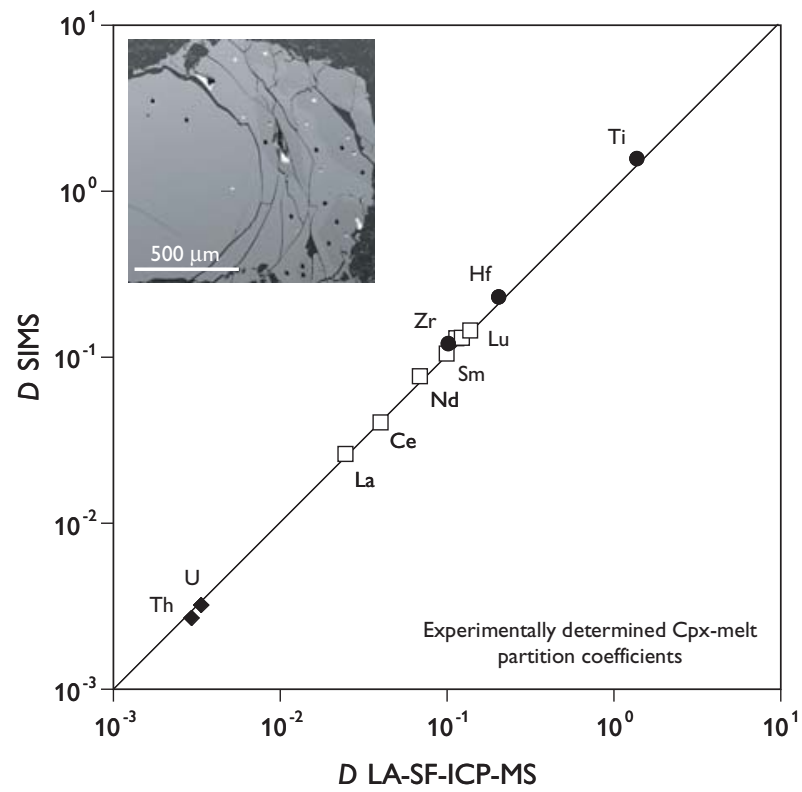

Fig. 6. Comparison of clinopyroxene-melt trace element partition coefficients (open symbols: REE; solid symbols: HFSE) determined from synthetic run products by SIMS and LA-SF-ICP-MS. Inset shows a BSE photomicrograph of synthetic, euhedral clinopyroxene coexisting with a glassy melt produced experimentally at high pressure and temperature. Shallow, bright spots are SIMS ablation pits (c. $20 \mu \mathrm{m}$ diameter), while deeper, dark spots are laser ablation pits (c. $30 \mu \mathrm{m}$ in diameter).

more widely available, LA-ICP-MS is increasingly used for the trace element analysis of synthetic geomaterials.

The inset in Fig. 6, for example, shows a back-scattered electron photomicrograph of an experimental charge containing euhedral clinopyroxene and a coexisting anhydrous silicate melt. The experimental charge was synthesised in order to determine the clinopyroxene-melt trace element partition coefficients $D_{\mathrm{i}}$ (defined as $D_{\mathrm{i}}=$ [concentration of $\left.\mathrm{i}\right]_{\mathrm{cpx}} /$ [concentration of $i]_{\text {melt }}$ ), knowledge of which is important for geochemical melt modelling purposes (Landwehr et al. 2001). In order to test the ability of laser ablation techniques to correctly determine partition coefficients from such experimental charges, we have analysed clinopyroxenes and coexisting silicate melts from a number of experiments with both SIMS (at the NERC ion-microprobe facility in Edinburgh) and LA-SF-ICP-MS (at GEUS). The resulting partition coefficients determined by SIMS and LA-SF-ICP-MS are graphi- cally compared in Fig. 6 for a representative sample. For all investigated samples, the partition coefficients determined by SIMS and LA-SF-ICP-MS are in excellent agreement, clearly demonstrating the reliability of laser ablation techniques for the characterisation of synthetic geomaterials.

\section{Acknowledgements}

The establishment of the new LA-SF-ICP-MS facility was funded with a grant of the Danish Ministry of Education and Technology to the Geocenter Copenhagen ('Geocenterbevilling') and financial support by GEUS. PV thanks the DAAD for awarding a PhD scholarship.

\section{References}

Aftalion, M., Bowes, D.R. \& Vrána, S. 1989: Early Carboniferous U-Pb zircon age of garnetiferous, perpotassic granulites, Blanský les massif, Czechoslovakia. Neues Jahrbuch für Mineralogie, Monatsheft 4, 145-152.

Charrier, R. 1979: El Triásico en Chile y regiones adyacentes de Argentina: Una reconstrucción paleogeográfica y paleoclimática. Comunicaciones 26, 1-37.

Harlov, D.E., Johansson, L., Van Den Kerkhof, A. \& Förster, H.-J. 2006: The role of fluid flow and diffusion during localised, solid-state dehydration: Söndrum Stenhuggeriet, Halmstad, SW Sweden. Journal of Petrology 47, 3-33.

Hollis, J.A., Frei, D., van Gool, J.A.M., Garde, A.A. \& Persson, M. 2006: Using zircon geochronology to resolve the Achaean geology of southern West Greenland. Geological Survey of Denmark and Greenland Bulletin 10, 49-52.

Jackson, S., Pearson, N.J., Griffin, W.L. \& Belousova, E.A. 2004: The application of laser ablation - inductively coupled plasma - mass spectrometry to in situ U-Pb zircon geochronology. Chemical Geology 211, 47-69.

Janoušek, V., Gerdes, A., Vrána, S., Finger, F., Erban, V., Friedl, G. \& Braithwaite, C.J.R. 2006: Low-pressure granulites of the Lišov massif, Southern Bohemia: Viséan metamorphism of late Devonian plutonic arc rocks. Journal of Petrology 47, 705-744.

Landwehr, D., Blundy, J.D., Chamorro-Perez, E.M., Hill, E. \& Wood, B.J. 2001: U-Series disequilibria generated by partial melting of spinel lherzolite. Earth and Planetary Science Letters 188, 329-348.

Steenfelt, A., Hollis, J.A. \& Secher, K. 2006: The Tikiusaaq carbonatite and associated kimberlites: a new alkaline magmatic province in the Nuuk region, southern West Greenland. Geological Survey of Denmark and Greenland Bulletin 10, 41-44

Wiedenbeck, M., Allé, P., Corfu, F., Griffin, W.L., Meier, M., Oberli, F., von Quadt, A., Roddick, J.C. \& Spiegel, W. 1995: Three natural zircon standards for U-Th-Pb, Lu-Hf, trace element and REE analysis. Geostandards Newsletters 19, 1-23.

Vermeesch, P. 2004: How many grains are needed for a provenance study? Earth and Planetary Science Letters 224, 441-451.

\section{Authors' addresses}

D.F., J.H. \& C.Kn., Geological Survey of Denmark and Greenland, Øster Voldgade 10, DK-1350 Copenhagen K, Denmark. E-mail: df@geus.dk

A.G., Institute of Mineralogy, Johan-Wolfgang-Goethe University, Senckenberganlage 28, D-60054 Frankfurt, Germany.

D.H., GeoForschungsZentrum Potsdam, Section 4.1 Experimental Geochemistry and Mineral Physics, Telegrafenberg, D-14473 Potsdam, Germany.

C.Ka. \& L.F., Department of Geology, University of Lund, Sölvegatan 12, S-22362 Lund, Sweden.

P.V. \& G.F., Institut für Angewandte Geowissenschaften, Technische Universität Berlin, Ernst-Reuter-Platz 1, D-10587 Berlin, Germany. 